\title{
The Correlation Between the Knowledge Improvement on Early Identification of Speech Disorder in Children Under 3 Years and the Motivation of the Posyandu Cadres Through the Dissemination of Degabbi Poster
}

\author{
$1^{\text {st }} \mathrm{S} \mathrm{H}$ Sheba \\ Speech Pathology Study Program \\ Al Islam Polytechnic of Bandung \\ 120 Cisaranten Kulon street \\ Bandung-Indonesia \\ $\underline{\text { shianehanako2014@gmail.com }}$ \\ $4^{\text {th }}$ W Winarti \\ Speech Pathology Study Program \\ Al Islam Polytechnic of Bandung \\ 120 Cisaranten Kulon street \\ Bandung-Indonesia
}

\author{
$2^{\text {nd }} D$ Nuramdiani \\ Speech Pathology Study Program \\ Al Islam Polytechnic of Bandung \\ 120 Cisaranten Kulon street \\ Bandung-Indonesia
}

$5^{\text {th }}$ M H Arifin

Program Studi Pendidikan Guru Sekolah

Dasar, Universitas Pendidikan Indonesia

Kampus Cibiru

Jl. Raya Cibiru KM 15, Bandung, Jawa

\author{
$3^{\text {rd }}$ E R Arum \\ Speech Pathology Study Program \\ Al Islam Polytechnic of Bandung \\ 120 Cisaranten Kulon street \\ Bandung-Indonesia
}

\begin{abstract}
The purpose of this study was to find out the knowledge level of posyandu cadres on the detection of speech disorders in toddlers and the relationship between the knowledge and their motivation to redisseminate it through a poster of speech disorders detection in toddlers (DeGaBBi). The research method was cross sectional design involving cadres from Rusunawa Health Center in Bandung, Indonesia. The statistical analysis using Pearson Product Moment was performed. The results showed that the average value of knowledge increased by $32.40 \%$. Meanwhile, the motivation was shown by $88,7 \%$ cadres through their maximum scores of the questionnaires. Regression analysis between the knowledge and motivation explained that the improvement of knowledge had a positive impact, although the correlation category was very weak $(r=0,052)$. Knowing that the motivation of the cadres to redisseminate the poster was good and only had a weak correlation with their level of knowledge, then further activities are to evaluate the content and display of the poster and to write a dissemination module to make the following dissemination more effective and the poster very understandable. Finally, the revised poster can increase the knowledge of the cadres comprehensively. Therefore, cadres are able to perform the early detection optimally.
\end{abstract}

Keywords-Speech Disorder, Children, Posyandu

\section{INTRODUCTION}

Speech and language disorders often occur in children. In the USA, speech and language disorders have a prevalence of $5 \%-12 \%$ (median $6 \%$ ) in children aged 2 to 5 years. (1) Speech and language disorders in preschool children that are not handled appropriately will have serious and lasting effects even into adulthood. School-age children who have a history of speech and language disorders at their preschool ages are at higher risk of learning disabilities in language-based subjects especially reading and writing disabilities. (2) Furthermore, adults who have a history of speech and language disorders at their preschool ages have lower work skills and are at risk of being laid off from work. (3)

Intervention in speech and language disorders will be optimal if it is carried out in the golden period of a child development, before the age of 5 years, at which brain and nervous system are still growing. (4) Accordingly, early detection efforts involving all relevant parties especially parents of children under five years are needed. However, this research is focused mainly to children under three years so that the intervention can be applied during their golden age.

Efforts to detect early speech and language disorders in children can be conducted through posyandu program which is one of the most basic centers in implementing education and public health monitoring as a form of the frontline community participation. Activities performed at posyandu are based on the role of posyandu cadres in monitoring the growth and development of toddlers so that they can detect any abnormality early, including speech and language 
disorders, and establish communication with parents especially mothers. According to their roles, efforts to increase community awareness about early detection of speech and language disorders can also be done by posyandu cadres and to ease the cadres to understand the related information they need an interesting and easily accepted media. As the result, an early detection poster of language and language disorders in toddlers have been created by using a cartoon character icon named DeGabbi (Deteksi dini Gangguan bahasa dan bicara; Early Detection of Language and Speak Disorders) so that the poster is more interesting and easier to remember.

The DeGabbi poster consists of a modification of the reference indicative table in delays and speech and language disorders in preschool children, distinguishing the signs and symptoms of speech disorders in some age levels of preschoolers. (5) (6) (7) Dissemination trials of the DeGabbi Poster were then conducted by inviting the posyandu cadres from the area of Puskesmas (Community Health Center) Rusanawa in Arcamanik District of Bandung.

The working area of the health center covers Cisaranten Kulon and Cisaranten Endah subdistricts, which have a population of 35,122 people (10,358 households) with a total of 4,104 children under five years. Based on the data, it can be estimated that using the prevalence in the USA of $6 \%$ the number of children under five who suffer from speech disorders in Rusunawa Health Center is about 246 children. (1)

Considering the above fact, it is important to know the level of knowledge and motivation of the cadres in the health center area in disseminating the early detection of speech disorders in toddlers through the poster media of DeGabbi so that the effectiveness of the poster and the dissemination can be evaluated. Effective dissemination and poster are expected to have high leverage in detecting speech disorders early so that they can participate in improving the quality of Indonesian human resources.

\section{MATERIAL AND METHOD}

The research subjects were posyandu cadres from Cisaranten Endah and Cisaranten Kulon subdistricts attending the DeGabbi poster dissemination. With the total of 81 cadres, 32 cadres came from Cisaranten Endah and 49 cadres came from Cisaranten Kulon. The data collection technique was purposive sampling involving all posyandu cadres present at the dissemination.

This research used cross sectional design by giving the cadres two tests, before the dissemination (pre-test) and after the dissemination (post-test). Meanwhile, the motivation of the cadres was measured by the instrument given along with the post-test questions.

The collected test answer sheets were then selected by the completeness of pre-test and post-test answer sheets as well as motivation instruments. Cadres filling either the pre-test or post-test are included in the exclusion criteria.

After that, the selected complete answer sheets were scored and the difference between the pre-test and post-test scores was calculated. Meanwhile, the level of motivation was gained by converting the motivation score to the Likert scale successively from score 4 for the highest motivation to score 1 for the lowest motivation. Finally, both data were analyzed statistically using Pearson Product Moment to find out the correlation and regression between the level of knowledge and motivation of the posyandu cadres.

\section{RESULT}

Results of the study with the subject of 81 posyandu cadres coming from the subdistricts of Cisaranten Endah and Cisaranten Kulon of Arcamanik District of Bandung Municipality can be seen in the following description. The selection process of 81 questionnaire answer sheets resulted in 62 complete and analysable answer sheets. Results of the measurement of the level of knowledge and motivation of posyandu cadres in the Rusunawa Health Center on early detection of speech disorders in toddlers are shown in the following figure.

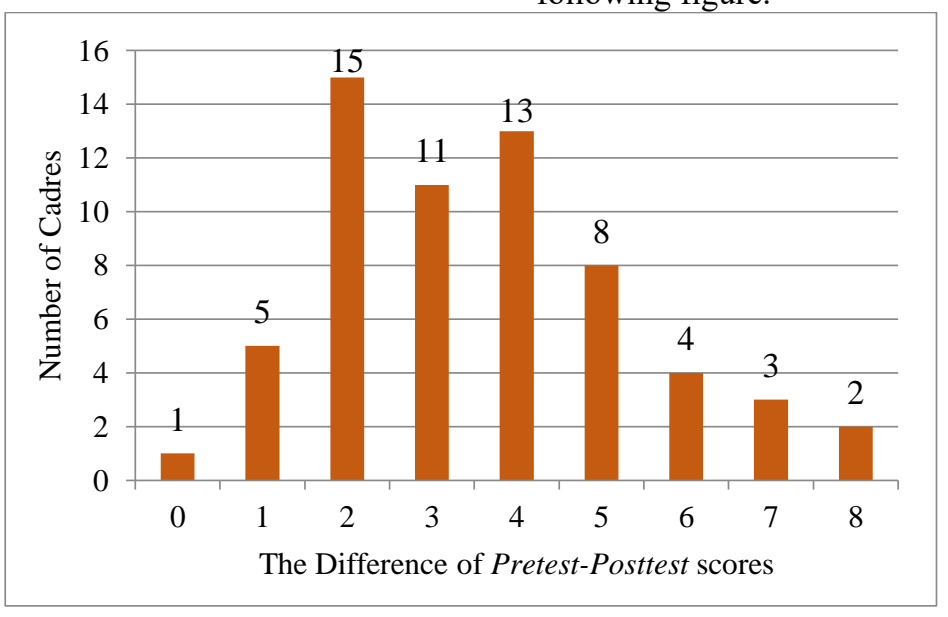

Fig. 1. The distribution of knowledge improvement frequency of posyandu cadres in rusunawa health center on early detection of speech disorders in children under 3 y $(n=62)$

Figure 1 describes that relating to knowledge there is still a cadre who has similar scores of pre-test and post-test (does not increase) after the dissemination of the poster, while the highest frequency occupied by 15 cadres occurs in score of 2 improvement. The maximum score of improvement ( 8 scores) is achieved by 2 cadres. 
TABLE I. THE DISTRIBUTION OF MOTIVATION LEVEL FREQUENCY OF POSYANDU CADRES IN THE RUSUNAWA HEALTH CENTER ON EARLY DETECTION OF SPEECH DISORDERS IN CHILDREN UNDER 3 Y $(\mathrm{N}=62)$

\begin{tabular}{|c|r|r|}
\hline Motivation Scores & $\begin{array}{c}\text { Number of } \\
\text { Cadres }\end{array}$ & \% \\
\hline 0 & 1 & 1,6 \\
\hline 1 & 0 & 0 \\
\hline 2 & 0 & 0 \\
\hline 3 & 0 & 0 \\
\hline 4 & 2 & 3,2 \\
\hline 5 & 1 & 1,6 \\
\hline 6 & 2 & 3,2 \\
\hline 7 & 1 & 1,6 \\
\hline 8 & 55 & 88,7 \\
\hline Total & 62 & 100,0 \\
\hline
\end{tabular}

Table 1 explains that the majority of cadres $(88.7 \%)$ have a maximum motivation value to redisseminate the early detection of speech disorders in toddlers in their area, only 1 cadre has no motivation at all, and there is a small portion $(9.6 \%$ cadres $)$ who have motivational values between $7-4$.

TABLE II. THE MEASUREMENT OF KNOWLEDGE IMPROVEMENT OF POSYANDU CADRES IN RUSUNAWA HEALTH CENTER ON EARLY DETECTION OF SPEECH DISORDERS IN CHILDREN UNDER 3 Y $(\mathrm{N}=62)$

\begin{tabular}{|l|c|c|}
\hline & Average Score & Percentage (\%) \\
\hline Pre-test & 5,77 & 52,5 \\
\hline Post-test & 9,34 & 84,9 \\
\hline Difference & 3,56 & 32,4 \\
\hline
\end{tabular}

Table 2 describes that the knowledge of posyandu cadres has increased as much as $32.4 \%$ from the average value of $52.5 \%$ on the pre-test before the dissemination to $84.9 \%$ on the post-test after the dissemination.

Results of statistical analysis using Pearson Product Moment to assess the linear regression between the knowledge improvement and motivation of the cadres showed a positive effect with a value of $\mathrm{Y}=7.48+0.037 \mathrm{X}$. It means that the higher the test scores improvement is, the higher the motivation of the cadres will be. However, the linearity relationship is not significant with a value of $p=0.69(p>0.05)$ and the correlation between the knowledge improvement and the cadres' motivation also shows a very weak correlation as can be seen at $r=0.052$. (8) Therefore, in general, it can be concluded that the motivation of posyandu cadres to redisseminate the information about early detection of speech disorders has little to do with the knowledge improvement gained during the dissemination.

\section{DISCUSSION}

The results of data analysis on the dissemination of early detection of speech disorders in toddlers show the slight differences on the knowledge improvement before and after the information was delivered to the cadres. Consequently, evaluations on the information delivery activities such as short delivery time, a sufficient number of cadres, as well as the method of presentation in the form of lectures without any practice or simulation are considered important. (9) These deficiencies can be revised by writing a dissemination module and limiting the number of participants to increase the effectiveness of the dissemination. (10) The module written is expected to increase the knowledge of cadres, which is in accordance with previous research reports stating that the availability of appropriate training modules for cadres can improve the knowledge, attitudes and skills of cadres in carrying out their duties. (11) (12)

Although there was only a slight knowledge improvement, the motivation of the cadres to redisseminate the related material to people living in their environtment was high. The fact is opposite to previous research describing that cadres' knowledge can increase their motivation to redeliver the information about early detection of children growth and development. (13) Hence, it is necessary to find out other factors related to the high motivation of cadres beside knowledge factor.

Some other factors to consider in encouraging high motivation of cadres may come from their self-confidence and pride when they get involved in the dissemination program as participants; their awareness that the new knowledge they are going to receive will be useful for surrounding community; supports from other cadres; and the availability of DeGabbi poster. The supporting factors of the cadres' performance mentioned above are in accordance with one of the studies explaining that non-financial factors that support the performance of cadres include: appreciation and respect for the work done by the cadres, valuable skills training, self-development opportunity, supports among cadres, and the availability of working instruments to identify cadres such as uniforms or identity card and to help them doing their work. (14) (15)

\section{CONCLUSION}

Based on the results of research and discussion, it was found that the results of data analysis on the spread of early detection of speech disorders in toddlers showed a slight difference in increasing knowledge before and after information was conveyed to cadres.

Several other factors that need to be considered in encouraging highly motivated cadres may come from their self-confidence and pride in being involved in the socialization program as participants; their awareness that the new knowledge they will receive will benefit the surrounding community; support from other cadres; and availability of DeGabbi posters.

\section{REFERENCES}

[1] Law J, Boyle J, Harris F, Harkness A, Nye C. Prevalence and natural history of primary speech and language delay: findings from : systematic review of the literature. Int J Lang CommunDisord. 2000; 35(2): 165-188.

[2] Catts HW, Fey ME, Tomblin JB, Zhang X. A longitudinal investigation of reading outcomes in children with language impairments. J Speech Lang Hear Res. 2002; 45(6): 1142-1157.

[3] Law J, Rush R, I.Schoon , Parson S. Modeling developmental language difficulties from school entry into adulthood: literacy, mental health, anc employment outcomes. J Speech Lang Hear Res. 2009; 52(6): 14011416

[4] Law J, Garret Z, Nye C. Speech and language therapy interventions for children with primary speech and language delay or disorder. Cochran $€$ Database Syst Rev. 2003;: CD04110.

[5] Feldman HM. Evaluation and Management of Language and Speech Disorder in Preschool Children. Pediatrics in Review. 2005; 26(04) 131-142.

[6] Mclaughlin MR. Speech and Language Delay in Children. American 
Family Physician. 2011; 83(10): 1183-1188.

[7] Leung AKC. Evaluation and Management of the Child with Speech Delay. American Family Physician. 1999 June; 59(11): 3121-3128.

[8. Walpole RE, Myers RH, Myers SL, Ye K. Probability and Statistics forn engineers \& scientist 434. 8th ed.: Pearson education, inc; 2007.

[9] Lestari W KHPIW. A qualitative study: The promotion of exclusive breastfeeding (EBF) by integrated service post (ISP) cadres in suburban city. Enferm Clin. 2019; 29: 56-59.

[10] Billot D. Development and experimentation of a health promotion and health education module in the context of an on-line. Sante Publique. 2007; 19(1): 53-65.

[11] Jumiyati , Nugrahaeni SA, Margawati A. Pengaruh Modul terhadap Peningkatan Pengetahuan, Sikap dan Praktek Kader dalam Upaya Pemberian ASI Eksklusif. Gizi Indonesia. 2014; 37(1): 19-28.

[12] Glenn JS. Knowledge, Perceptions, And Attitudes Of Managers Coworkers, And Employed Breastfeeding Mothers. AAOHN Journal 2008; 56(10): 423-429.

[13] Aticeh , Maryanah , Sukamti S. Pengetahuan Kader Meningkatkan Motivasi dalam Melakukan Deteksi Dini Tumbuh Kembang Balita. Jurnal Ilmu dan Teknologi Kesehatan. 2015; 2(2): 71-76.

[14] Iswarawanti DN. Kader Posyandu: Peranan dan Tantangan Pemberdayaannya dalam Usaha Peningkatan Gizi Anak di Indonesia. Jurnal Manajemen Pelayanan Kesehatan. 2010; 13(04): 169-173.

[15] Pardasani M. Motivation to volunteer among senior center participants. J Gerontol Soc Work. 2018; 61(3): 313-333. 